\title{
Paulus en mag: Raamwerke en aansprake
}

\begin{abstract}
Author:
Jeremy Punt ${ }^{1}$

Affiliation:

${ }^{1}$ Faculty of Theology,

University of Stellenbosch,

South Africa

Note:

This article was initially presented as a paper at the NavNUT Conference 'Mag in die Nuwe Testament', on 16-19 January 2011 at the University of Stellenbosch, Stellenbosch, South Africa.

\section{Correspondence to:}

Jeremy Punt

Email:

jpunt@sun.ac.za

Postal address:

Private Bag X1, Matieland

7602 , South Africa

Dates:

Received: 12 Oct. 2011

Accepted: 23 Jan. 2012

Published: 10 Apr. 2012

How to cite this article:

Punt, J., 2012, 'Paulus

en mag: Raamwerke en aansprake', HTS Teologiese Studies/Theological Studies 68(1), \#Art. 1186, 11 pages. http://dx.doi.org/10.4102/ hts.v68i1.1186
\end{abstract}

C 2012. The Authors. Licensee: AOSIS OpenJournals. This work is licensed under the Creative Commons Attribution License.
Paul and power: Framing claims. Evidently an important theme in the Pauline letters, discussions of the nature, scope and function of power have given rise to a wide range of explanations and interpretative positions. Engaging the rich diversity regarding the content and nature of power in Paul, this contribution argues that the Roman imperial context is indicative and instrumental for understanding the construction and regulation of power in the Pauline letters. Coming to terms with the significance of imperial ideology in the understanding of power in Paul requires appropriate interpretive strategies such as a postcolonial interpretation.

\section{Inleidende uitgangspunte}

Daar is in die verlede oor 'n breë spektrum verwys na die dinamika van mag in die Nuwe Testament en die Pauliniese briewe, onder andere na die mag van sonde (bv. Gaventa 2007:125136); die mag van die Evangelie (bv. Eastman 2007:181-194; Patte 1983; Savage 1996); en die mag van gesag (bv. Castelli 1991; Holmberg 1978; Polaski 1999). Sodanige studies speel in op die rykdom en diversiteit van die tema van mag in die Nuwe Testament, te midde van die wye verspreiding daarvan in die eerste-eeuse wêreld. Hiërargies en patriargaal opgestel, in 'n wêreld gebaseer op slawerny en 'n samelewing georganiseer in terme van idees en aksies wat gebaseer was op die beskermheer-onderdaan verhouding, met ' $n$ agonistiese samelewing waar waardes van eer en skaamte sekere aksies en lewenstyle veronderstel het, was die habitus ${ }^{1}$ van die Nuwe Testament tye diep gekleur deur mag. Op die koop toe, en in samehang met genoemde sosiale praktyke, was die sosio-politieke wêreld gekonstrueer en gedefinieer deur die Romeinse Ryk met 'n wyd verspreide maar gevarieerde teenwoordigheid in die Mediterreense wêreld.

Een van die implikasies van 'n wêreld deurdrenk met konstellasies van mag van verskillende tipes is dat spesifieke of toegespitste studies van woorde wat 'mag' vertaal soos byvoorbeeld

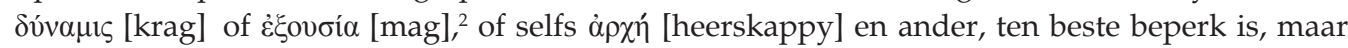
by tye selfs verwarrend mag wees; nie alleen as gevolg van wat ingesluit word nie, maar ook as gevolg van wat deur sodanige studies uitgesluit word. Geen enkele term slaag daarin om die diskoerse of dinamiek van mag in die Pauliniese briewe volledig te ondervang nie, en aangesien mag telkens in die versweë agtergrond van die briewe aanwesig is, is dit nie alleen van bepaalde terminologie afhanklik nie (kyk Polaski 1999:122). Trouens, die alreeds beperkte waarde van woordstudies oor mag word geïnhibeer deur die oorheersing van idealistiese benaderings tot Bybelnavorsing. ' $n$ Idealistiese benadering tot mag reduseer alle historiese gebeure en prosesse tot blote idees, en sien alle historiese ontwikkelinge, konflikte en invloede as ontwikkelings, konflikte en invloede bloot tussen idees (alreeds afgewys deur Holmberg 1978:205-207). Uiteraad beïnvloed dit die navorsing, en plaas dit 'n stremming op die breër of voller verstaan van mag in die Nuwe Testament. 'n Gekompromiteerde metodologie gebaseer op 'n historiese rekonstruksie wat teologies bepaald is, verwaarloos of negeer selfs die deurlopende dialektiek tussen idees en sosiale strukture. ${ }^{3}$ In teenstelling hiermee, moet die sosiale funksie eerder as die oorsprong van spesifieke idees en oortuigings beklemtoon word soos inderdaad ook gebeur in kritiese benaderings tot die Pauliniese briewe. ${ }^{4}$ Só 'n fokus vereis 'n herwaardering van belangrike

1.Bourdieu (1997:95) verduidelik habitus as 'an acquired system of generative schemes objectively adjusted to the particular conditions in which it is constituted'. Habitus is dus 'both the collection of schemes informing practice and the generative source of new or modified practices' (Morgan 1998:7).

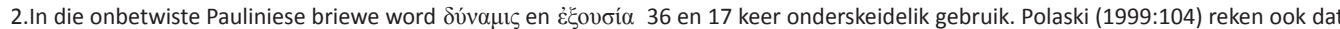

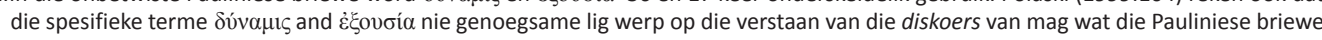
onderlê nie.

3.Die probleem is nie dat die ondersoek na historiese verskynsels nie noukeurig gedoen word nie; dit is eerder dat sodanige verskynsels volledig na teologiese idees herlei word en die verskynsels as totaal afhanklik daarvan beskryf word, wat die metodologie kwesbaar stel: 'secondary reaction ... on primary, concrete phenomena in the social world ... is misinterpreted as being the structural principle stel: 'secondary reaction .... on primary,
of that world' (Holmberg 1978:205).

4.Ideologies-kritiese benaderings tot Paulus is uiteraard nie noodwendig sonder fout of vooroordeel nie, maar om alle interpretasies wat met ' $n$ hermeneutiek van suspisie bedryf word, summier af te maak as noodwendig anakronisties, simplisties en reduksionisties wat met ' $n$ hermeneutiek van suspisie bedryf word, summier af te maak as noodwendig anakronisties, simplisties en reduksionisties
(Johnson 1998:12-29), is ' $n$ oorvereenvoudiging en tekenend van die krag van yking en konvensies in die geskiedenis van interpretasie. In die woorde van Castelli (1991:23): 'a spiritualizing gesture towards the text assumes the transparency of textual reference while remaining silent on the question of the interestedness of the text. 
begrippe soos mag, asook Paulus se verhouding met die gemeenskappe waarmee hy interaksie gehad het, ten minste in soverre as wat dit uit sy briewe afgelei kan word. ${ }^{5}$

Die bestudering van Paulus se verhouding tot mag, insluitend sy leierskap en uitoefening van mag in die gemeenskappe wat hy in sy briewe aanspreek, kan verskillend benader word. Met die bespreking van ' $\mathrm{n}$ aantal onlangse benaderings en opsigte van mag en Paulus as my vertrekpunt en raamwerk, is my fokus hier om die noodsaak van die Romeinse imperiale konteks as basies tot die verstaan van mag by Paulus te beklemtoon. Meer nog, met die imperiale konteks nie alleen as agtergrond nie, maar ook as voorgrond, met ander woorde, as interpretatiewe konteks sowel as ' $n$ heuristiese raamwerk vir sy briewe, ${ }^{6}$ is die postulering van 'n eksklusiewe, antiimperialistiese gerigtheid by Paulus ontoereikend. Paulus se hantering van mag is verweef met die kompleksiteit van lewe in ' $n$ onderdrukkende bestel, ingebed in ' $n$ worsteling oor mag op verskillende vlakke. Hiervoor word 'n gepaste hermeneutiese benadering vereis, soos byvoorbeeld ' $n$ postkoloniale interpretasie wat in staat is om die dinamika van mag wat in ander interpretasie raamwerke uitgesluit word, uit te lig. ${ }^{7}$

\section{Paulus en mag: Skopus of referente}

Verskillende kategorieë en onderskeidings word dikwels ingespan om die onderskeie konstellasies van mag binne die Pauliniese briewe aan te dui, insluitende goddelike en metafisiese mag (Black 1984; Johnson 1998); ${ }^{8}$ sosiale mag (Wan 2008); retoriese mag (Wanamaker 2003; Collins 2008); of selfs interpretatiewe mag (Fowl 1994:78, n. 4). 'n Onderskeid ten opsigte van die styl of toonaard van mag, insluitende sake soos outoritêre mag9 (contra Eastman 2007) of gedeelde mag, of verskillende kombinasies daarvan, word ook soms getref. Bykomend tot die kategorië alreeds genoem is kontekste van mag belangrik, met verwysing na Paulus se verhouding met sy opponente (kyk Wan 2008); met sy medewerkers en

5 .'So, Paul's activity as a communities' organizer is served by ideas whose purpose is to establish a community with enough sense of common endeavour that they can survive as distinct, and viable, groups in the social contexts. Justification by faith alone is less an article of faith than a technique of social cohesion used to weld disparate ethnic and social groups together. The maintenance of social identity is enabled by strategies of ideological polemic. Ancient traditions are appropriated and reinterpreted in favour of the new group. So the Abraham story function as legitimating story not of the election of the Jewish nation but for those who espouse the law-free gospel' (Rowland 2006:660-661).

6.Carter (2010:18-19) vind 'the reframing and promotion of the Roman imperial world from background and context to the central entity that Paul and his communities actively negotiate, imitate, and contest', besonder insiggewend in sy onlangse werk oor Paulus en die Romeinse Ryk.

7.Verder is my benadering kultuur-krities, wat ten minste twee belangrike vertrekpunte impliseer: eerstens, om nie noodwendig met Paulus (van die briewe) te identifisee nie, en nie summier sy aansprake as normatief te reken nie. Tweedens, Paulus word nie geag as identities tot die gemeenskappe wat hy aanspreek nie, of wannee hy homself só voorstel, nie noodwendig aanvaar as die bepalende stimulus of onbevraagtekende leier van sodanige gemeenskappe nie (kyk ook Schüssle Fiorenza 2000:44). Met ander woorde, om 'n gepredisponeerde gevolgtrekking te vermy word daar nie aan die historiese Paulus soos gekonstrueer uit sy briewe summier hermeneutiese voorrang verleen nie. Oor die noodsaaklikheid van hermeneutiese verantwoordbaarheid, kyk Kittredge (1998:1-6).

8.Mag in die Nuwe Testament word 'anders' (in Engels, 'other-wise-ly') verwoord (kyk Johnson 1998:6-10 vir breedvoerige teksverwysings), onder andere omdat mag ook as iets van buite, afkomstig van ' $n$ transendente oorsprong soos byvoorbeeld die Gees, belewe word.

9.Paulus word dan nie beleef as iemand wat met outoritêre styl skryf nie, maar eerder as pastor, bemiddelend en aanmoedigend; kyk Verhey (1984:103) oor die Pauliniese pastoraal-etiese styl as appèl eerder as bevel. gemeenskappe; ${ }^{10}$ met bose magte (bonatuurlik, kosmies, en ander metafisiese magte); en selfs ook met homself (bv. Rom 7), en natuurlik ook met God (bv. 2 Kor 10-13).

Hedendaagse filosowe dra verder by tot denke oor mag, en bevraagteken dikwels geykte denkpatrone. Mag moet byvoorbeeld nie oorvereenvoudig word tot ' $n$ negatiewe entiteit ingestel op oorheersing en selfs geweld, of tot ' $n$ eenduidig positiewe krag gemik op die bemagtiging van almal op gelyke wyse nie. Mag hoef allermins as beperkende krag verstaan te word nie, want dit kan produktief wees, miskien juis omdat dit in tussenareas aangetref word, te midde van liminaliteit en dikwels onbepaald, interafhanklik en versprei dwarsdeur die sosiale bestel. Mag is dus nie primêr repressief of beperkend nie, nie in die eerste plek mag-oor, of die alleenreg van sommige nie. Mag word nie ervaar of beperk deur mense met sekere doelstellings nie, maar dit is eerder ' $n$ geval dat mag ' $n$ wye reeks van gevolge toelaat, gevolge van diverse en dikwels dubbelsinnige aard, aangesien mag verhoudings en die erkenning van sekere kennisvorme produseer. Mag-kennis verhoudings kan ontwikkel op maniere wat verwagtings weerspreek, en lei tot 'n reeks gevolge, selfs met inbegrip van die teenkanting van die dinamika van sodanige magswerkinge (kyk Foucault; Marchal 2008:66).

Nuwe pogings om mag te verstaan en sosio-histories te plaas, het tot sterk reaksies onder sommige Bybelwetenskaplikes aanleiding gegee. Die ondersoek van die interaksie tussen mag, die metafisiese én sosiale realiteite word bevraagteken deur diegene wat sodanige werk sien as ' $n$ poging om transendente mag te verbloem onder ' $n$ sosio-politieke dekmantel. Die vroeë Jesus-beweging sou dan kwansuis as weinig meer as ' $n$ reeks politieke en ideologiese aansprake wees (Johnson 1998:25, 36). In reaksie sou 'n historiese en fenomenologiese benadering eerder toelaat vir die bestudering van die optrede van Jesus-volgelinge as ' $n$ respons tot die transendente mag van die opstanding. Met ander woorde, alhoewel die geldigheid van die aansprake van die Jesus-volgelinge aanvaar word, word geen ontologiese afleidings op grond van sodanige aansprake gemaak nie. ${ }^{11}$ Met die totstandkoming van vroeë Jesus-gemeenskappe vorm mag deel van ervaring, en is terselfdertyd die verwysingspunt van sodanige ervarings. ${ }^{12}$ Uiteindelik word beweer, word alle ervarings en linguistiese uitdrukkings gesien as sou hulle die intensionele referent van mag openbaar, alhoewel betekenisvolle intensionele strukture van religieuse verskynsels nie noodwendig korrespondeer met materiële objekte nie.

10.Kyk Lieu (1986:132) vir hoe Paulus probeer bemiddel het tussen die mag waarop hy aanspraak gemaak het en die evangelie wat hy verkondig het, en die sosiale en huishoudelike verhoudings en lojaliteite van die tyd.

11.Om bestaansvrae tersyde te plaas, maak ' $n$ fenomenologiese posisie (Johnson se voorkeur) moontlik. Maar Johnson se implisiete aanvaarding dat die intensionele referent teenwoordig is in die bewussyn van vroeë Jesus-volgelinge, asook as ontiese werklikheid, ondergrawe sy eie metodologiese posisie (bv. Johnson 1998:59, 185; kyk Dijkhuizen 2010:12)

12. Mag word dus as ' $n$ bruikbare analitiese kategorie gesien om die data van die vroee Jesus-beweging te verstaan, aangesien die Nuwe Testament ' $[i s]$ literally filled with the language of power' (Johnson 1998:46). 
Alhoewel godsdienstige ervaring onmiskenbaar belangrik is vir die verstaan van die Pauliniese briewe, het godsdienstige ervaring met sosiale realiteite ten minste net soveel te doen as met die transendente. 'n Goeie voorbeeld word in die brief aan die Galasiërs gevind waar Paulus in 'n groot mate staat maak op godsdienstige ervaring vir sy argument. Nie alleen het die ervaring van die Galasiërs (Gal 3:1-5) gedien as belangrike merker van Paulus se evangelie en dus sy mag nie, maar Paulus bied ook sy eie ervaring aan om sy aansprake te bevestig en dié van sy oponente af te wys (Gal 12). Op grond van sy persoonlike godsdienstige ervaring vestig hy die geldigheid van sy boodskap as openbaring van God (Gal 1:11-12), en beklemtoon terselfdertyd die verskil tussen hom en die ander evangelieverkondigers. ${ }^{13}$ Die appèl op die Galasiërs om hul eie ervaring van Christus en die Gees na aanleiding van Paulus se ervaring te verstaan, lê Paulus se pogings om identiteit in terme van groepsolidariteit te bevestig, bloot. Naas ' $n$ basis vir die aanspraak op uniekheid en bron vir groepsolidariteit, dien Paulus se beroep op ervaring ook die doel om die gemeenskap op sosiale wyse te (her)definieer, deur grenslyne tussen binne- en buitestaanders te trek. Ervaring speel inderdaad dus 'n belangrike en bepalende rol vir die sosiale kontrole en mag wat Paulus in Galasiërs uitoefen (Wan 2008:67-81). Maar sodanige debatte oor die verstaan van mag as uitsluitlik ' $n$ transendente krag of in samehang met sosiale realiteite, vorm deel van 'n nog veel omvattender raamwerk vir die bespreking van die tema. Die afspeel van materiële en metafisiese magte teen mekaar is tipies van moderne kategorieë van verstaan maar 'n onvoldoende beskrywing van eerste-eeuse persepsies.

\section{Raamwerke vir en debatte oor Paulus en mag}

Mag het vir eerste-eeuse mense'n breë spektrum van materiële magte, persoonlik en struktureel, en metafisiese magte, goddelik en andersins, persoonlik en struktureel, ingesluit. Hul leefwêreld was ondenkbaar sonder magsverhoudings en -manifestasies. Die geleefde werklikheid as primêre konteks wat mense se verstaan van mag bepaal het, was 'n materiële wêreld waarin mag genormaliseer en gekonvensionaliseer en daarom genaturaliseer is. ${ }^{14}$ Die probleem met, en dalk selfs die oorsprong van praktyke wat mag by Paulus verdoesel deur dit te individualiseer of te vergeestelik, is geleë in teoretiese tekortkominge, die gebrek aan gepaste benaderings of metodologië om met die komplekse, verweefde en dikwels wedersyds-konstituerende verhoudings van verskillende wêrelde van mag rekening te hou (kyk Leesstrategie en -houding hieronder).

\section{Paulus en mag: Stragegië, bronne, aansprake}

Die strewe na 'n geloofwaardige raamwerk vir die konstellasie van mag en Paulus, asook gepaste interpretatiewe meganismes,

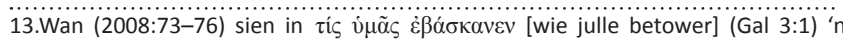
duidelike aanduiding dat Paulus die gesag van die opponente in Galasië uitgedaag het. Besetenheidsbeskuldigings is meestal tussen gelykes gemaak met positiewe aandrang om aansien te bevorder, terwyl towerybeskuldigings meer dikwels deur ondergeskiktes in gemarginaliseerde posisies gemaak is, gemik daarop om beide
die status quo en die gesag van die leiers en magsfigure uit te daag.

14.'n Belangrike oorweging is om die verdoeseling van mag deur mistieke taal, insluitend spiritualiserende en individualiserende meganismes in die interpretasie van die Pauliniese briewe te weerstaan. benodig eers ' $n$ kort opgawe oor die magdinamika by Paulus. Selfs deur slegs op drie aspekte van die magdinamika te fokus, is die ambivalensie in sy briewe alreeds duidelik, en pogings om Paulus te vrywaar van die manipulering van mag onder verdenking. Paulus maak in die eerste plek daarop aanspraak dat sy mag ontspring in en direk afhanklik is van sy bewussyn van sy apostoliese verantwoordelikheid. Telkens verwys Paulus in sy briewe na ' $\mathrm{n}$ roepingsbewustheid, om vir ' $\mathrm{n}$ spesifieke taak toegewys te wees (selfs al voor sy geboorte, Gal 1:15) deur God vir die boodskap oor Christus. Sy apostoliese roepingsbewustheid blyk reeds uit sy selfbekendstellings as $\dot{\alpha} \pi$ ó $\tau 0 \lambda$ o $\varsigma$ [gestuurde of apostel] (Rom 1:1; 1 Kor 1:1; 2 Kor 1:1; Gal 1:1), ${ }^{15}$ wat duidelik as tegniese term eerder as 'boodskapper' in die algemene sin van die woord gebruik word. Nieteenstaande ' $n$ sterk bewussyn van sy apostoliese gesag, gee sy briewe weinig aanduiding dat hy dit volledig of op direkte wyse vir eie voordeel gebruik (kyk egter 1 Kor 5:3-5). Selfs waar Paulus probeer om sy lesers te oortuig en hul samewerking te verkry soos in die Filémonbrief, maak hy nie direk op apostoliese gesag aanspraak nie, en dring nie op voorskriftelike wyse aan op hul gehoorsaamheid op grond van 'n bevoorregte posisie nie. ${ }^{16}$ Paulus se styl word daarom dan as nie-outoritêr beskryf, een van beleefde versoeke eerder as outoritêre vereistes, in 'n gees van vryheid en verantwoordelikheid in Christus (bv. Verhey 1984:103).

Maar die saak is veel meer kompleks, aangesien die briewe self, natuurlik, met inbegrip van die oënskynlike selfontmagtiging, gesien kan word as ambivalent en deel van 'n subtiele of ironiese ommekeer. Die briewe kan gelees word as dat hulle juis ingestel is op die verkryging van vrywillige onderdanigheid as die toppunt van mag - om ander oor te haal tot jou posisie sonder om die indruk te skep dat hul daartoe verplig is. Dit kan goedsmoeds die geval wees dat, soos Stirewald onlangs beweer het, Paulus se apostoliese beskrywing in sy briewe aan ' $n$ ambassadeursbeeld gelyk gestel word. ${ }^{17}$ Trouens, aansprake oor Paulus se nie-outoritatiewe styl, oor sy apostoliese identiteit as konsekwent selfafwysend, sonder sweem van selfbelang of menslike swakheid, kom in gevaar wanneer ander navorsing oorweeg word. Hoe Paulus se oproepe tot navolging, beide sy aansprake op gesag, en oproepe as gevolg daarvan, ten grondslag lê (Castelli 1991); hoe Paulus se diskoers van gehoorsaamheid parallel geloop het aan die oorheersende Grieks-Romeinse imperiale elitekultuur (Kittredge 1998);

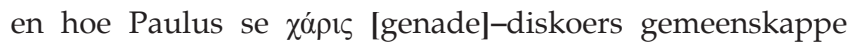

15.Dit is interessant dat Paulus net in 3 briewe nie na homself as apostel verwys nie. In 1 Tessalonisense stel hy homself nie as $\dot{\pi}$ ó $\sigma \tau 0 \lambda$ o $\varsigma$ voor nie, en verwys ook nie na homself 1 Tessalonie na homself met hierdie term

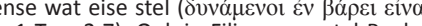
alhoewel ons met gesag kon optree], 1 Tess 2:7). Ook in Filippense, stel Paulus

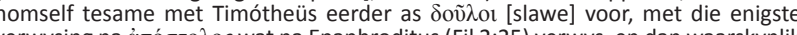

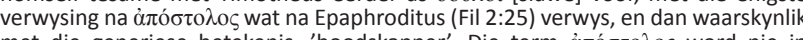

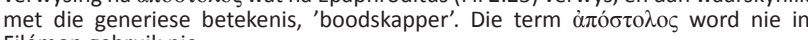
Filémon gebruik nie.

16.Alhoewel die wyse waarop Paulus in Film aanspraak maak op gesag en instemming verlang, meer subtiel en heelwat meer gekompliseerd is (kyk Punt 2010b:223-250 onlangs ook Elliott 2011:51-64).

17.Stirewalt reken dat Paulus doelbewus die amptelike eerder as persoonlike briefvorm gebruik het, in aansluiting by sy selfuitbeelding as gesant van God (Stirewalt 2003:37), wat met goddelike gesag optree as tussenganger tussen God en die jurisdiksie van die gemeentes (Stirewalt 2003:54). Stirewalt se posisie dat Paulus in sy briewe doelbewus en bekwaam homself as goddelike gesant en ussenganger uitgebeeld het, laat vrae ontstaan oor die retoriese en politieke effe daarvan op die ontvangers van sy briewe? Maar skaad 'n outoritêre styl nie die boodskap uiteindelik nie, en wat is die effek hiervan op die pastorale effek van Paulus se kommunikasie? 
gepredisponeer het om aan Paulus gesag te verleen en sy mag te erken (Polaski 1999)..$^{18}$

Tweedens, die gesag van Paulus se argumente het dikwels hulle ontstaan uit 'n appèl op grond van die geskrifte van Israel, of sy argumente is daarmee in gedagte gekonstrueer; en, by tye is sterk standpuntinname ook in verband gebring met en bevestig deur die geskrifte (bv. Rom 9-11; Gal 3-4 veral 4:30). Sommige navorsers meen dat Paulus die geskrifte ter ondersteuning van sy posisie gebruik het, en ook die aard van mag soos gevind in die geskrifte onderskryf het. Die dinamika van mag waarmee Paulus hom sou assosieer, sou dan sy oorsprong hê in 'n goedgunstige God wat konsekwent en sonder uitsondering ${ }^{19}$ mag op 'n positiewe manier uitgeoefen het, gemik daarop om veral die lewens van minderbevoorregtes en gemarginalieerdes te goede te wees (Ehrensperger 2009:9, 13, 15, veral 71-78) - maar so 'n standpunt ignoreer die 'toornige God' wat wraak neem op sy vyande, selfs met oproep tot ekplisiete geweld (kyk Desjardins 1997). Alhoewel minder navorsers tans nog oortuig is dat Paulus die geskrifte slegs aangehaal het om opponente se standpunte te weerlê, ${ }^{20}$ maak Paulus se gebruik daarvan in sy argumente en aansporings duidelik dat sy eie gesag op hierdie wyse in ieder geval positief bevestig word: ${ }^{21}$ in kort, God steun Paulus se posisie (Stanley 2004:176-178).

Die punt is dat Paulus geïmpliseer word in sy eie diskoers van mag aangesien geskrifte-aanhalings ook gedien het om sy aansprake te onderskryf, sy posisie gesag te verleen, en sy argumente en posisie te regverdig. ${ }^{22}$ Soos elders in groter detail aangetoon is, wanneer Paulus se briewe in die konteks en ideologiese raamwerk van die Romeinse Ryk gelees word, is daar genoegsaam rede om sy briewe as sterk maar subtiel uitdagend teenoor die Romeinse Ryk te verstaan. Die uitdaging is ondersteun en bekragtig deur sy interpretasie van die geskrifte. Nie alleen het hy die geskrifte as raamwerk ingespan in sy briewe nie, maar dit ook gebruik om sy boodskap en apostolaat te beaam. Trouens, volgens Paulus was sy eie bediening so diepgaande verweef met die geskrifte dat sy oponente se houding teenoor hom terselfdertyd hul houding daarteenoor gereflekteer het. ${ }^{23}$ Met die goddelike

18.Vir kritiek ten opsigte van Castelli se werk oor mimesis in die Pauliniese briewe, kyk Witherington (2003:262); vir kritiek ten opsigte van Polaski se navorsing, kyk Ehrensperger (2009:63-80).

19.Kyk Crossan (2008:49-95) wat die ambivalensie ten opsigte van mag in die Bybel met ' $n$ appèl op God ontsluit, maar so die waarde van die Bybel ten opsigte van magsaangeleenthede prysgee.

20.Alhoewel die geskrifte deur Paulus gesagvol gebruik is (kyk Stockhausen 1990:196-197), kan Von Harnack se standpunt dat Paulus die geskrifte net inroep as polemiese gereedskap teen die Judaïserende opponent nie gehandhaaf word nie (kyk Silva 1993:638,639), aangesien hy ook die geskrifte inroep wanneer hy van ingeburgerde tradisies verskil (bv. in Gal 3 oor die wet en of dit lewe gee). Vir ' $\mathrm{n}$ ander posisie, kyk Scott (1993:187-221).

21.Meer radikaal, dink Cook (2002:182-191) dat Paulus se opponente in Galasië die slagoffers van sy vervolgingswerk was, en dat Paulus nou met ' $n$ idiosinkratiese lees van die geskrifte reageer.

22. Ruimte laat nie ' $n$ volledige bespreking toe nie, maar verdere nadenke oor 'marginalisasie' in die Paulusbriewe moet ook die plek en rol van die geskrifte in Paulus se denke insluit. Sy gebruik van tekste en temas het onvermydelik daardie sake van hul skriftuurlike raamwerk ontworstel, en - ten minste ten dele - die Bybelse raamwerk as geheel. Kyk Boyarin se beskuldiging oor Paulus se dele - die Bybelse raamwerk as geheel. Kyk Boyarin se beskuldiging oor Paulus se 2004); ook Stanley (2004:28-29) ten opsigte van Meir Sternberg se werk oor die verplasingseffek van aanhalings.

23.Stanley (2004:40) is waarskynlik reg om te beweer dat die gesag van die geskrifte wyd erken is onder die vroeë Christelike volgelinge van Jesus, met die gevolg da Paul se gebruik van die geskrifte tot sy posisie in die beweging sou bygedra het. gesag van die geskrifte, het Paulus aangespraak gemaak op niks minder nie as goddelike sanksie vir sy bediening en boodskap (Punt 2008:290). Paulus se beroep op herinneringe wat nuwe lewe aan die tradisies gegee het, het egter ook ' $n$ wederkerende effek gehad, naamlik om 'n tradisie te vestig en gesag aan sodanige herinneringe te verleen. ${ }^{24}$ Hierdie wederkerigheid vereis dat dieper gekyk moet word in en deur die tekste as wat Paulus se weergawe van herinnering en gebeure toelaat, ten einde ' $n$ meer toereikende idee te vorm van die verskillende ervarings van die sosiale realiteite wat deur Paulus aangeraak word..$^{25}$

Derdens, die verhouding tussen Paulus en mag, gedeeltelik afhanklik van en gekonstrueer deur die geskrifte, was verwant aan die apostel se opvattings oor vryheid. Trouens, miskien was Paulus se vryheid sy exousia (Hays 1989:156). Nie alleen het die geskrifte deel uitgemaak van Paulus se verwantskap met mag nie, maar die gedagte van die nabyheid van die skrifwoorde het beteken dat lesers bemagtig sal word deur die Gees tot verbeeldingryke intertekstuele lesings, wat die getuienis van die Wet en die Profete sou belig as die Evangelie van God se geregtigheid (Hays 1999:180). Uiteraard word Paulus ook dikwels aangehaal as die aankondiger van 'n vryheid wat selfs veel wyer strek: vryheid van die Wet, sonde en die dood - vryheid van verslawing aan enige en alle materiële en metafisiese wesens.

Dit is egter duidelik dat vryheid vir Paulus nie die herkenning van ' $\mathrm{n}$ innerlike selfstandigheid wat alle mense van nature besit nie en die basis van Christelike vryheid van verslawing sou kon uitgemaak het, was nie. Sonder om Paulus op anakronistiese wyse aan moderne idees oor vryheid te meet, blyk dit dat aanduidings dat etnisiteit, gender, en slawerny tersyde gestel is (Gal 3:28) heroorweeg moet word (kyk Punt 2010c). Vryheid was immers afhanklik van 'n groter mag, die aanvaarding van ' $n$ verpligting teenoor God wat alle ander oortref, insluitende byvoorbeeld teenoor eienaars en weldoeners (vgl. 1 Kor 7:22; Briggs 2000:113). Waarskynlik moet Paulus se metaforiese gebruik van slawerny in die sterk sin van die woord verstaan word. ${ }^{26}$ Die resultaat was dat Paulus se retoriek van slawerny nie alleen die retoriek van sy eie posisie ten koste van ander stemme en tradisies versterk het nie, maar ook menslike lewe met slawerny gelyk gestel het. ${ }^{27}$

24.In Paulus se gebruik van tekste, is die mag van die woord en die dwingende potensiaal in die gebruiksreg van die geskrifte duidelik. 'Their [texts] embeddedness and social functions are paradigmatic, but th" the way texts construct rears hierarchies engendered, and by the authoritative voice claimed' (Lieu 2004:25).

25.Paulus nie soseer as individu nie, maar eerder as ' $n$ lid van die gemeenskappe wat hy aangespreek het (Punt 2011a). Want 'memories are not one-way tracks ... If the past casts a shadow on the present through memory, the present also imposes on the past by means of memory' (Xu 1994:265).

26.'Slavery was not a simile for the Christian's [sic] relationship to Christ and God. Paul was not making an analogy between one aspect of two dissimilar relationships. Rather, he was speaking of an identical relationship in two dissimilar realms wherein enslavement to Christ and God displaced the social institution. ... The phrases in [1 Cor] 7:22, "freed person belonging to the Lord" and "slave of Christ", were in [1 Cor] 7:22, "freed person belonging to the Lord "and "slave of Christ", were intended by Paul to inculcate in Christians the same sense of dependence on an obligation to Christ that were owed by a slave to a slaveowner or by a freed person
to his or her patron' (Briggs 2000:114).

27.'This position reinforces both the slavery metaphor and the kyriarchal social system implied with that metaphor as a given in early Christian discourse' (Kittredge 1998:178) 
Die dubbelsinnigheid wat duidelik aanwesig is in al drie hierdie gevalle waar Paulus se verhouding met mag ter sprake kom, asook debatte en betwiste areas oor hoe om die beste sin te maak van Paulus en mag, gaan mank aan 'n agterweë gelate maar sentrale aspek, die verrekening van die Romeinse Ryk as ' $\mathrm{n}$ bepalende sosio-politieke faktor. Die meningsverskille tussen geleerdes oor die verstaan van die konstellasie, dinamika of diskoers van mag verleen die nodige invalshoek ${ }^{28}$ vir die evaluering van die Romeinse Ryk as gepaste sosiale plasing en heuristiese raamwerk vir Paulus en mag.

\section{Die Romeinse Ryk as sosiale konteks en interpretasie raamwerk Romeinse Ryk as gepaste konteks}

Paulus en van sy praktyke is in die verlede al as idiosinkraties beskryf (bv. Hays 1989 oor sy gebruik van die geskrifte), maar die aard van Bybelwetenskap verlang nietemin dat ' $n$ geloofwaardige sosio-historiese konteks as interpretatiewe raamwerk vir die verstaan van Bybelse tekste en persone gevind word. ${ }^{29}$ Die daarstel van ' $\mathrm{n}$ geloofwaardige sosiohistoriese konteks, agtergrond sowel as voorgrond, as heuristiese en hermeneutiese raamwerk impliseer geen aanspraak op objektiwiteit, op eksklusiwiteit of noodwendig op prioriteit nie, nóg vir die raamwerk nóg vir agentskap van die raamwerk. ${ }^{30}$ Die belang van Joodse, Grieks-Romeinse en selfs breër Hellenistiese raamwerke is uiteraard belangrik vir die verstaan van Paulus se opmerkings oor mag en inderdaad ook oor swakheid (en ander kontraste soos wysheid of dwaasheid). ${ }^{31}$ Die impak van die alomteenwoordige en magtige Romeinse Ryk mag egter nie uit die oog verloor word nie ${ }^{32}$ - soms juis ook as belangrike mede-element van die ander raamwerke. Wydverspreide verwaarlosing van die imperiale konteks word dikwels die spreekwoordelike olifant in die vertrek waarvan almal bewus is en waardeur sommige selfs ontstel word, maar wat nogtans nie verreken word nie. ${ }^{33}$

Soms word blote lippediens betoon aan die Romeinse Ryk as verstaanskonteks, soos wanneer sommige geleerdes

28.Vir eerste tree in die verrekening van die Romeinse Ryk as sosio-historiese konteks en heuristiese raamwerk in NT studie, kyk Punt (2010a:1-7).

29.'n Kort, relevante voorbeeld van die belang van konteks: Paulus se neiging om sy eie beuel te blaas hoef nie as blote arrogansie of surplus selfvertroue verstaan te word nie. In die eerste eeu was openlike aanspraak op dade, en gunste teenoor ander mense, en ook opleiding en onderrig vir verskillende redes as belangrik beskou en het gedien as bevestiging van identiteit, sowel as manlike status in die openbare oog (Malina \& Neyrey 1996).

30.Eerder die teenoorgestelde: naamlik om subjektiewe voorveronderstellings te erken asook die noodsaaklikheid om die insigte van ander te oorweeg en te tolereer.

31.Dwaasheid as 'vroulike' eienskap word die konteks of raamwerk vir die verstaan van Paulus se retoriek van dwaasheid (Polaski 2005:5, 19-20, 62, 76). Ook in die Galasiëgemeenskap sou die beskuldiging van dwaasheid (Gal 3:1, 3) in die hierargiese, patriagale eerste eeu as genderbelediging gesien gewees het, met inboet van status (Bassler 2007:45)

32.Meer en minder as die Grieks-Romeinse samelewing: minder, in die sin van die oorweldigende impak van die Romeins-imperiale ideologie op alle vlakke en deur alle media; meer, in die sin dat die Romeinse Ryk sterk op die Hellenistiese wêreld met alles wat dit gebied het, gesteun het vir eie, imperiale voordeel.

33. If the central figure of the Christian faith was executed on a sedition charge by the occupying forces of the Roman Empire, and if the early churches took root and grew in an imperialist setting, then why is there so little theorizing in biblical studies about empire and religion?' (Friesen 2001). beweer dat Paulus mag primêr deur die lense van die geskrifte van Israel verstaan het. Eerder as om in te speel op heersende Grieks-Romeinse waardes, sou Paulus doelbewus dan die gedagte- en waardesisteem van die heersende Grieks-Romeinse samelewing probeer dekonstrueer, ${ }^{34}$ en beïnvloeding teengestaan het..$^{35}$ Helaas faal die afwysing van imperiale ideologiese beïnvloeding van mag en Paulus, en die aanname van sy afkeer van Grieks-Romeinse politieke en ekonomiese waardes, omdat dit die wydverspreide invloed van die Romeinse Ryk sowel as die aantrekkingskrag ${ }^{36}$ en subtiele invloed ${ }^{37}$ van die Ryk buite rekening laat. Paulus begin miskien wel 'n ander diskoers van mag, en weliswaar met sy retoriek wat steun op die geskrifte vir geloofwaardigheid en gesag. Maar, soos hierbo reeds gesuggereer is, Paulus se aanpak vertoon sterk ambivalensie. Aan die een kant staan Paulus se posisie teenoor dié van die Ryk. Hy onderhandel mag op retoriese vlak, met die diskursiewe kolonialisme van imperiale ideologie en met die ontvangers van sy briewe ook met die geskrifte wat nuwe betekenis kry wanneer hulle deur hom opgeneem word. Aan die ander kant, ontkom Paulus nie volledig aan beïnvloeding deur die Romeinse Ryk nie.

\section{Sosiale konteks en heuristiese raamwerk vir mag}

Die Romeinse Ryk was 'n konstellasie van strukture, owerheidsisteme en sosiale stelsels en konvensies, 'n komplekse verweefdheid waarbinne mag sentraal gestaan het. Wanneer die wydverspreide teenwoordigheid en gepaardgaande impak van die Romeinse Ryk in terme van afhanklikheid van die imperiale teologie, die ideologiese gom wat die Romeinse samelewing bymekaar gehou het, beskryf word (Crossan 2008:59-62), maak dit die belang vir die interpretasie van Paulus selfs duideliker. Eerstens, was die Romeinse wêreld as beskawing, mitologies, godsdienstig en ook op teologies afhanklik van 'n viervoudige basis van mag. ${ }^{38}$ Die Romeinse beskawing het berus op imperiale teologie wat op sy beurt afhanklik was van die goddelikheid

34.Collins reken nie dat die retories-begaafde Paulus moes kies tussen sy ingesteldheid op die Grieks-Romeinse wêreld, die imperiale stad, of die taal van die geskrifte nie (Collins 2008). En Carter (2010:24) waarsku dat pogings om die lang, volgehoue verwaarlosing om Paulus se interaksie met die Romeinse Ryk te verreken, nie ten koste van Paulus se Joodsheid en interaksie met eerste-eeuse Jodendom moet gebeur nie.

35.'[T] he imperial context had a significant impact on the dynamics of power to which the Pauline texts bear witness ... But to acknowledge such influence is not the same as to propose that they shared these aspects' (Ehrensperger 2008:1011 , oorspronklike klem; kyk 36-37; 55, 59; 71, 78; 98-116 veral 103, 110, 113, 115-116; 153; 191-193).

36.Ryksattraksie ('attraction of Empire') is nie noodwendig gemik of affiliasie of deelname nie, maar kan ook die mimikretiese ('mimicrying') doel beslaan om
soortgelyke voordele te bekom as dié wat imperiale affiliasie meebring (soos mag, soortgelyke voordele te bekom as dié wat imperiale affiliasie meebring (soos mag,
status, rykdom), selfs al is dit volgens ander maatstawwe en vir ander doeleindes.

37.Ehrensperger se benadering is ontoereikend vir ' $n$ aantal ander redes ook. Alhoewel sy ten regte die belang van Israel se geskrifte en gepaardgaande tradisies vir Paulus se denke en optrede beklemtoon, is die aanname van die konsekwente teenwoordigheid daarvan en omgekeerd, die volslae afwesigheid van die alomteenwoordige Grieks-Romeinse waardes, by Paulus gelykstaande aan spekulasie en romantisering, selfs veralgemening en oorvereenvoudiging. Daarmee saam, om waardes soos gelykheid, wederkerigheid, en verhoudingsmatigheid opsommenderwyse aan die geskrifte van Israel toe te dig as volledige en dominante beskrywing daarvan, is misleidend.

38.'Military power as the monopoly or control of force and violence; economic power the monopoly or control of labor and production; political power, the monopoly or control of organization and institution; and ideological power, the monopoly or control of meaning and interpretation' (Crossan 2008:60; kyk Mann 1986:518522). 
van die keiser, sodat die keiserkultus ${ }^{39}$ onbetwis was asook die breër uitwaaier van imperiale teologie. Derdens, die bevordering van imperiale goddelikheid tesame met ideologiese ondersteuning en gepaardgaande praktyke was nie alleen beperk tot afgeleë provinsies nie maar was selfs nader aan Rome teenwoordig. Vierdens was die sukses van Romeinse imperiale teologie grootliks afhanklik van openbare blootstelling daarvan op effektiewe wyse en deur die aanvaarding daarvan deur die elite wat bande gehad het met imperiale strukture (kyk bv. Ando 2000). Vyfdens, Romeinse imperiale teologie het staatgemaak op subtiele en indirekte verwysings na die goddelikheid van Augustus, ook terwyl hy nog geleef het. ${ }^{40}$ In die sesde plek, goddelike status is toegeken aan keisers as beide ' $n$ dinastiese en imperiale prerogatief, binne Julio-Claudiese (veral Julius Ceasar en Augustus) maar later ook die Flaviese dinastieë (veral Vespasianus, Titus en Domitianus). En in die sewende plek, Romeinse imperiale teologie was in 'n groot mate bevorder deur beelde en strukture, insluitende poësie, inskripsies, munte, standbeelde, altare en ander strukture (kyk Friezen 2001; Price 1984; Zanker 1990). In kort, die Romeinse Ryk se teenwoordigheid was aanvoelbaar in konkrete en op sigbare wyse $^{41}$ (kyk ook Punt 2010a:1-7).

Die uitstaande kenmerk van die Romeinse politieke ideologie was dominasie en onderdrukking, dikwels op subtiele wyse. Een goeie voorbeeld was die retoriek van clementia (kyk Elliott 2008b:87-119), dat die Ryk oor die beswil van alle mense begaan was. ${ }^{42}$ Die oorweldigende en dikwels vernietigende krag van die Romeinse Ryk op militêre, sosio-kulturele, ekonomiese en godsdienstige vlak het parallel geloop met die ideologiese aanspraak dat die Ryk op die welsyn van alle mense gerig was. In kort, ' $n$ ideologie wat beskawing deur oorlog, en vrede deur geweld onderskryf (kyk Punt 2010a:17). Die konteks van 'n alomteenwoordige Romeinse Ryk het onvermydelik die bewussyn en wêreldsiening van eersteeeuse Mediterreense mense beïnvloed. Meer as ' $n$ sosiohistoriese realiteit was die Romeinse Ryk ook 'n heuristiese raamwerk vir Paulus se verstaan van God, die lewe en die kosmos. Sy briewe moet in die lig van die Romeinse Ryk en die invloed daarvan verstaan word, maar ook sin maak van die impak en invloed van die Ryk, en imperiale teologie en ideologie op Paulus se denke. Gegee die wydreikte van die Ryk se materiële en ideologiese teenwoordigheid, is die bewyslas nie eerder op diegene wat poog om die impak en invloed van imperiale ideologie op Bybelse outeurs af te

39 .Sosio-historiese en literêre ondersoek na die kultiese werking van die keiserkultus is belangrik, maar moet versigtig hanteer word. Dit mag nie maar net as ' $n$ religieuse on(der)ontwikkeling, ook in terme van die gepaardgaande 'teologiese' basis daarvan, afgemaak word nie. Ook mag dit as blote idiosinkratiese, opportunistiese onderneming van verbygaande aard uitgebeeld word nie.

40.Byvoorbeeld in Ovid (Tristia 3.1.36-39) waar Augustus uitgebeeld word as gereïnkarneerde Jupiter.

41.'The royal family, both the emperor himself and his predecessors, and his wife and children, were well known through statues and coins. From Spain to Syria, everybody knew about Rome, what it stood for, what it did, and who was in charge of it' (Wright 2005:64).

42.Die opinie dat clementia sedert Julius Casear met despotiese optrede geassosieer is, kan waarskynlik nie gehandhaaf word nie (Konstan 2005:337-346). Dat ' $n$ beroep om clementia wel in diens van imperiale ideologie gebruik is, is egter duidelik. wys nie ${ }^{43}$ Vir die Pauliniese literatuur was daar geen ander sosio-politieke konteks as die Romeinse Ryk nie, ${ }^{44}$ beide in openbare vorm van imperiale mag en heerskappy deur regeerders, leërs, en konvensies, maar ook meer subtiel.

\section{Mag: Krag en swakheid in Korinte}

Die belang van die Romeinse Ryk in hierdie bespreking is tweërlei. Aan die een kant was die Ryk 'n imperiale krag wat mag oor almal uitgeoefen het, met Paulus se tekste wat haaks daarteenoor gestaan het. Aan die ander kant kan Paulus se eie magsoptrede, soos verwoord in die tekste, ten beste vestaan word in terme van analogieë met imperiale propaganda. Een voorbeeld wat breedweg die belang van inagneming van die invloed van imperiale teologie in Pauliniese denke suggereer, is gepas. Die magstaal van sterk of swak soos dit ook in Paulus se Korintiese briewe gevind word (ook bv. Rom 14:1-15:1), skuur skouers met die ideologiese woordeskat van die Romeinse elite vir wie krag of mag met eer en rykdom gelykgestel was. ${ }^{45}$ Die Romeinse Ryk, imperiale samelewing, huishouding en liggaam was almal nou aan mekaar verwant, en swakheid was geïdentifiseer met die skaamte van laer klasse in besonder ${ }^{46}$ (Reasoner 1999; kyk Elliott 2007:185; Martin 1995:xviii, 47-55). ${ }^{47}$ Wanneer die Ryk van agtergrond tot voorgrond skuif in die Paulusinterpretasie, kan sy aansprake ten opsigte van mag en ook sy distansiëring daarvan, in 'n ander konteks geplaas word. Trouens, Paulus se magsaansprake kan vergelyk word met die imperiale propaganda dat die Ryk nie soseer oor eie mag begaan was nie maar eerder die belange en welvaart van mense in die algemeen op die hart gedra het.

\section{Viering van swakheid}

Veral in ' $n$ stad soos Korinte met sy strategiese politiese verbintenisse en plasing, en as belangrike skakel in handel, was die imperiale teenwoordigheid merkbaar in die talle aspekte van materiële kultuur (tempels, standbeelde, weldoenerskap, ensovoorts), op allerlei wyses deurdrenk met imperiale ideologie. Met eerste oogopslag, in kontras tot die Romeinse outoriteite en Augustus in besonder, het

43.Alhoewel die uitspraak dat godsdiens in die Romeinse Ryk nooit politiek uitgesluit het nie (bv. Segal 2000:189), algemene instemming vind, word die politieke element dikwels nie verreken nie, of die keuse van interpretatiewe instrumente maak die identifisering, blootlegging en ondersoek van die politieke dimensies moeilik of eenvoudig onmoontlik.

44.Segovia (1998:57) verwys na 'the massive presence and might of the Roman Empire, master and lord of the entire Circum-Mediterranean, with its thoroughly accurate if enormously arrogant classification of the Mediterranean Sea as mare nostrum.'

45.Vir die imperiale kultus as Paulus se vernaamste teenstander in die Korintiese korrespondensie, kyk Saunders (2005:227-238). Given (2010:196-197) sien die rasionaal vir Paulus se klem op magstaal in 1 Korintiërs 1-4 as ' $n$ meer persoonlike aangeleentheid, naamlik sy poging tot 'rhetorical power over against those who have become enamoured with Apollos.'

46.Swakheid was op die koop toe ' $n$ genderkonsep. Byvoorbeeld in 1 Korintiërs 7:3638 , 'Paul's exclusive address to the young man thus reveals his assumption of the male-female hierarchy of strength' (Martin 1995:227; kyk ook nota 32).

47.In lewendige debatte oor Paulus en die Romeinse Ryk is een groot twispunt hoe Paulus se interaksie met die Ryk verstaan kan word (Carter 2010:19). My argument hier - en elders - is nie dat die Pauliniese briewe uitlsuitlik, of as konstante of direkte uitdaging van die imperiale ideolit . subtiele impak van die Romeinse Ryk en imperiale teologie, wat nie altyd uitgedaag nie maar ook onderhandel, nageboots, heringerig, ensovoorts word in Paulus se briewe. 
Paulus in 1 Korintiërs 1-4 en 2 Korintiërs 4-5, 10-13 op swakheid eerder as krag gefokus. Al gou word dit duidelik dat swakheid vir Paulus beide ' $n$ wyse van transformasie en ' $n$ teken van die realiteit daarvan was (Hollingshead 1998:217-220, kyk Eastman 2007:100).

Met ' $n$ beroep op die liggaam van Christus as mishandelde maar opgewekte liggaam laat dit Paulus 'n posisie van weerstand teen die imperiale magte van die dag verwoord, en terselfdertyd dien dit as basiese verwysingspunt vir diegene wat ly onder die onderdrukkende regime. ${ }^{48}$ In Korintiërs word die indruk dat Christus die slagoffer van die Romeinse Ryk was, gekombineer met die beeld van die een wat deur God in ere herstel is deur die opstanding. ${ }^{49}$ Paulus sien die dood as die voorloper tot die opstanding met die teenwoordigheid van die Gees as eerste vrugte of waarborggetuienis vir die opstanding (Punt 2011b). Nie alleen was Paulus oortuig dat Jesus se volgelinge ook die kruis en opstanding liggaamlik moes ervaar nie; selfs meer belangrik nog was daar vir hulle geen ander keuse was nie, aangesien hulle die liggaam van Christus was (kyk Hollingshead 1998:208-210).

Die vergoeiliking en uitlewing van swakheid het haaks gestaan op die heersende sentiment van die dag en veral teenoor die Romeinse ideologie met sy fokus op status en hiërargie, op gesag, mag en kontrole, beklemtoon in die openbare viering van hierdie aspekte deur middel van prosessies, monumente, tempels en muntstukke, om enkeles te noem. Maar as kontra-diskoers het die viering van swakheid ook nuwe geleenthede vir mag gebied.

\section{Swakheid as die nuwe krag?}

Sodanige aansprake op swakheid en die gepaardgaande ommekeer van waardes het inderdaad vir Paulus die geleentheid tot andersoortige wyses van magsuitoefening gebied. Sommige geleerdes beweer dat Paulus die kruis en opstanding histories en teologies aanmekaar verbind het in sy briewe, en dat die dood en opstanding van Christus vir Paulus 'n enkele komplekse gebeurtenis van redding was (Boers 2006:137). Maar wanneer hierdie twee temas in terme van hul impak op mag en kontrole geëvalueer word, is die verskil tussen beklemtoning van kruis of opstanding voor die hand liggend. Terwyl die kruis swakheid as deug gesimboliseer het, aangesien transformasie deur swakheid bereik is en terselfdertyd ' $n$ teken van sodanige swakheid was, ${ }^{50}$ wys opstanding eerder in die rigting van krag en oorwinning.

48.Swakheid het nie noodwendig vir Paulus kwiëtisme beteken nie: 'om te bly in God' ( 1 Kor 7$)$ is nie noodwendig ' $n$ passiwiteit nie, maar kan positief verstaan word. Die Korintiërs moet God se inisiatief handhaaf, God se mag wat menslike ideologie en mag oortref. So kan Paulus ook verstaan word as dat hy sosiale konserwatisme uitdaag en menslike magskonstruksies negeer. 'Remain with God' impliseer dan 'see what God is doing' (Kim 2008:58).

49.'The body as tortured, as crucified, must be carried about, represented, embodied in the persons of his apostles, until the deadly representations of the Empire's power are brought to an end by the One to whom all powers will ultimately be power are brought to an end by the One to whom all powers
subjected (1 Cor 15:24)' (Elliott 2004:87, oorspronklike klem).

50.Dit sou die heersende Romeinse sentiment met die beklemtoning van grootsheid uitgedaag het, veral ten opsigte van die elite wat geen moeite ontsien het om fisiese bewys van sodanige grootsheid ten toon te stel nie, soos byvoorbeeld in Augustus se Res Gestae (Hollingshead 1998:218).
Vir Paulus was die opstanding die bevestiging van die waarheid van die kruis (1 Kor 15:12-18). Sonder om konseptuele verbande of ambivalensie te ontken, was Paulus se keuse vir die inhoud van sy prediking nietemin die kruis van Jesus (1 Kor 2:2) en nie die opstanding nie (maar kyk kritiek van Given 2010). ${ }^{51}$ Tog, wanneer Paulus kruis en opstanding in sy argumente ontplooi, tree ' $n$ belangrike onderskeid na vore. Die belang van Christus vir Paulus self word deur die verrese Jesus onderskryf (bv. Fil 3:3-14; Gal 1:15-16), maar wanneer Paulus die betekenis van Christus vir sy lesers stel, lê Paulus klem op aspekte van Christus se dood, opstanding en verwagte wederkoms (bv. 1 Kor 15:3-7; Rom 6:1-14; Boers 2006:109). Paulus het klaarblyklik in sy aandrang op swakheid nie homself of sy werk mag ontsê nie. Swakheid mag dalk nie dieselfde wees as krag nie, maar wanneer swakheid magtig word, is dit nie tog 'n nuwe vorm van krag, hergedefinieerde mag nie? Paulus neem mag op deur swakheid as krag uit te beeld, 'n posisie wat 'n interessante vergelyking oproep met die aansprake van die Romeinse Ryk, dat hul magsuitoefening niks anders as altruïstiese diens aan die samelewing was nie.

\section{Paulus se retoriek van swakheid as uiting van mag}

In sy briewe aan die Korintiërs word Paulus se diskoers van mag gedra deur ' $n$ retoriek van swakheid (bv. 1 Kor 1-4; 2 Kor 10-13; kyk Fil 2:5-11) en ook 'n retoriek van dwaasheid (bv. 1 Kor 1-4) en beide kan as uitdagend teenoor die imperiale diskoers gesien word, en terselfdertyd as beskerming van Paulus se onbenydenswaardige posisie. Ander verklarings vir die ironie en subtiele opneem van mag deur die afwysing daarvan, is ook moontlik, maar die Romeinse Ryk se propaganda bied ' $n$ ooglopende en voorhande interteks. In die Korintiese korrespondensie met al die verskillende interessante hoeke, het Paulus veral in 1 Korintiërs 1-4 en 2 Korintiërs 12-13 'n sterk verdediging van sy bediening en apostolaat geloods. En dit is in hierdie dele waarin Paulus se anti-imperiale, marginale hermeneutiek en diskoers van mag in die praktyk waargeneem kan word. Alhoewel die retoriese gerigtheid van die briewe in die verlede dikwels as pastoraal beskryf is, gefokus op etiese opsies teen die agtergrond van 'n bevestiging van die paroesia en eskatologie in die algemeen, ${ }^{52}$ is daar ' $n$ groeiende bewuswording van die subversiewe of selfs anti-imperiale taal van 1 Korintiërs 1:20-25; 11:3; 15:2425 (kyk Rieger 2007:23, 36-37).

Die spanning inherent tot Paulus se gebruik van die krag/ swakheid binêre kontras in die Korintiese briewe is egter

51.Natuurlik, en soos Given (2010:193-198) graag uitwys, was Paulus se aanspraak om die kruis te preek ' $n$ retoriese instrument, en moet dit dus nie letterlik opgeneem word nie, soos sy briewe ook aantoon (bv. 1 Tess 1:9-10; 1 Kor 1-4 en 15; kyk selfs Hand 17:22-31). Trouens, nie net die opstanding nie, maar ook die koninkryk, oordeel en toekomstige heerskappy van God is by tye prominent in sy briewe (kyk 1 Kor 15:3-4, 24-25)

52.Die apokalipties-eskatologiese strekking van 1 Korintiërs is nie bloot ' $n$ poging om die oor-entoesiastiese Korintiese volgelinge van Christus hok te slaan nie. Die apokaliptiese tradisie is in wese anti-Ryk (kyk Rieger 2007:48-49), en in kontemporêre spreektaal, voorsien dit 'regime-change'. Die suggestie dat Paulus se hoë Christologie die vestiging van gemeentes as 'colonial outposts of the empire that is to be' was, en dat Paulus eerder as ' $n$ sendeling in religieuse drag as 'an ambassador of a king-in-waiting' van groepe van lojale volgelinge wat hul lewens gebou he op die Christus-verhaal, gesien kan word (Wright 2000:161-162), beklemtoon die verband tussen die pastorale en die politieke. Horsley (1997:242-252) beweer dat Paulus in 1 Kor strategieë geformuleer het oor hoe die Korintiërs hulself kon vestig as 'a community of a new society alternative to the dominant imperial society.' 
ook opvallend. ${ }^{53}$ As Paulus se retoriek nie in die eerste plek teen mag en die uitoefening van mag as sulks was nie, dan is ' $n$ ander verstaan van mag in Korinte moontlik: deur die krag van swakheid te beklemtoon word mag opgeëis! ${ }^{54}$ Die sarkastiese opmerking van 1 Korintiërs 4:8 met koninklike verwysing is nie alleen ' $n$ afwysing van die Korintiese aanspraak op mag deur geestesgawes nie, maar dit demonstreer ook iets van die konteks waarin so 'n retoriek van mag verstaan moet word. ${ }^{55}$ Die retoriek van swakheid is trouens meer as ' $n$ huiwerige erkenning van ' $n$ oorlog wat verloor is teen imperiale magte; daar is rede om te dink dat Paulus vir strategiese redes sy swakheid aan die groot klok gehang het. Sy liggaam was skynbaar reeds onder bespreking, onder andere vir teologiese redes, aangesien hy die voorbeeld van die lydende Jesus nageboots het (kyk Glancy 2004; Castelli 1991). Die aanspraak op swakheid en gebruik daarvan om mag te vestig, is dieselfde strategie wat Paulus elders in 1 Korintiërs gebruik (bv. 1 Kor 7:6-9). ${ }^{56}$

Die retoriese krag van Paulus se fokus op swakheid moet nie geringgeskat word nie (kyk Given 2010:193-198). ${ }^{57}$ Taal en 'n spesifieke diskoers vind nie alleen binne sosiale relasies plaas nie, maar konstrueer juis ook sodanige sosiale relasies (kyk Kittredge 1998:5). Paulus se retoriek in Korinte toon iets van 'n bewussyn van die ambivalente aard van mag asook van die ambivalensie van die posisie wat hy voorstaan, ${ }^{58}$ wat krag uit kragteloosheid voortbring. Maar Paulus se retoriek was nie daarop gemik om kandidate vir die koninkryk van Rome te werf nie; dit was waarskynlik eerder 'n poging om mag binne die Korintiese gemeenskap uit te oefen met 'n retoriek geïnspireer deur ironie en subtiele ommekeer propaganda - van die imperiale wêreld. Binne die konteks van 'n Romeinse Ryk wat aanspraak gemaak het daarop dat dit die beswil van alle mense op die oog gehad het, afstand gedoen het van willekeurige aansprake op mag, moeite gedoen het om by wyse van beeldpoetsers die pretensie van 'mag-tot' praktyke op te eis, word die kompleksiteit van Paulus se posisie duideliker.

\section{Leesstrategie en -houding}

Om die historiese en diskursiewe imperialisme wat die daaglikse lewe van eerste-eeuse mense op 'n verskeidenheid van maniere bepaal het, ook in terme van bewussyn

53.'Paul places himself in a position of rhetorical power in order to advocate a community based on weakness. There is thus an irony here, both textual and historical. Paul's writings are rich in almost every way, including ambiguity' (Hollingshead 1998:242).

54.'The weak Paul is equivalent to the offensive gospel. In 2 Cor 4:1-5:20; 10-13, Paul sets up a more elaborate contrast between the weak, suffering Paul and his gospel and the self-glorifying "super-apostles" who have some other - never described gospel (especially 2 Cor $11: 4-5$ ). What we may fail to notice is that Paul's rhetoric also associates himself with nothing less than divine glory (2 Cor 3:4-18). As a result, Paul's self-effacing rhetoric is ultimately quite aggrandizing' (Walsh 2005:41, n. 51) Kyk Wanamaker (2003:194-221) oor Paulus en mag in 2 Korintiërs 10-13 vanuit ' sosio-retoriese perspektief.

55.'Of course he means to claim the honor and authority of the title "spiritual" for himself and deny it to those Corinthians whom he immediately characterizes as "people of the flesh" (3:1 NRSV)' (Given 2010:195).

56.'[Paul] claims for himself the position of greater strength, then notes that he is wiling to be more flexible for the sake of weaker members' (Martin 1995:210).

57.Collins (2008) het onlangs oor die gebruik van metafore, en die krag van simboliek in Paulus geskryf.

58.Kyk Aasgaard (2007) oor die ambivelensie in Paulus se aanspraak op mag in swakheid in kontekste waar hy homself as kind verbeeld. en ideologie, te verreken, vereis meer as tradisionele hermeneutiese praktyke. Kan die paradigma verskuiwende impak van die beklemtoning van Paulus se interaksie met die Romeinse Ryk (Carter 2010:24) bereik word sonder 'n gepaste hermeneutiese raamwerk ${ }^{59}$ Die geskiedenis van die Paulusinterpretasie, en belang daarvan in die geskiedenis van dieChristendom, kompliseer pogings om die ambivalensie en die kompleksiteit van mag in die briewe sinvol aan te spreek. Terwyl tradisionele benaderings óf die imperiale olifant in die kamer miskyk óf nie daarin slaag om 'n greep daarop te kry nie, is die voordele van 'n postkoloniale benadering vir die ondersoek oor die impak van die Romeinse Ryk op die Pauliniese briewe byna vanselfsprekend. Meer nog, ' $n$ postkoloniale benadering het die insluiting van ontmagtigdes op die oog, om gedoofde of uitgeskakelde stemme van gekolonialiseerdes, gemarginaliseerde en onderdruktes te laat hoor. ${ }^{60}$ Ongelyke magsverhoudinge op geopolitieke en ander vlakke, met betrekking tot die Ryk en die verhouding tussen imperiale en koloniale, maar ook op sosiale en persoonlike vlakke van die magtige heerser en die onderdanige, word ondersoek om sodoende die verhouding tussen sentrum en periferie in spel te bring. ${ }^{61}$ By Paulus is daar van dubbele ambivalensie sprake: enersyds was Paulus 'n gemarginaliseerde onder die Ryk, met sy briewe wat as uitdagend teenoor die aansprake van die Ryk gelees kan word. Maar andersyds het Paulus op 'n leiersrol aanspraak in gemeenskappe, met sy retoriek mag opgeëis deur mag te relativeer.

Die kenmerkende benadering van postkoloniale kritiek is in die eerste plek te wyte aan nuwe aandag vir onderdaniges ('subalterns'). ${ }^{62}$ Dit bring verteenwoordiging ('representation') weer in spel, nie soseer in die mimetiese sin nie maar eerder in die erkenning en opname van die voormalig gekolonialiseerdes in die kronieke van die geskiedenis, en bevestig hul huidige agentskap soos voormalige versperrings afgebreek word. Aan die een kant is postkoloniale kritiek ' $n$ kontra-hegemoniese diskoers met spesiale aandag vir die

59. Die keuse van " $\mathrm{n}$ interpretatiewe raamwerk en die impak van die sosiale plasing van interpreteerders van Bybelse tekste speel natuurlik ' $n$ kritiese rol in eksegeties resultate (bv. Ricoeur 1980; Segovia \& Tolbert 1995a \& 1995b; Thiselton 1980).

60.Die skopus van postkoloniale studies beslaan, soverre operasionele wydte betref, die volledige spektrum van imperiale-koloniale formasies sedert antieke koninkryke tot die teenswoordige rykweidte van globale kapitaal; as onderliggende raamwerk word beide ekonomiese en politieke omgewings ingesluit, insluitende kapitalisme en modernisme (Segovia 2005:70-72). Byvoorbeeld met verwysing na die vroeë Jesusvolgeling-gemeenskappe, het die stad Rome ' $n$ metropolitaanse of imperiale sentrum gevorm, en areas soos die westelike en in besonder die oostelike mperiale sie antieke wêreld insluitende die subkontinente soos Asië, was periferale dele van die antieke wêreld, insluitende die subkontinente soos Asië, was periferale areas (Friesen 2001:17). Ander geleerdes bevestig die imperialisme-kolonialisme onderskeid, maar bevraagteken die gelykstelling daarvan met die sentrum-periferie
as wederkerend-bevestigende verhoudings (Marchal 2008:4-5, 128, n. 8).

61.Dit ondersoek terselfdertyd die verhouding maar ook die kontraste en onderskeid tussen sentrum en periferie. Postkoloniale interpretasie se fokus op verhoudinge van mag en hegemonie, met ander woorde op dominasie en onderdanigheid, is veral bruikbaar om die wye spektrum maar ook verbandhoudende areas van gender, ras, seksualiteit en ekonomie in Bybelse tekste en latere interpretasies daarvan te ondersoek. '[P]ostcolonial criticism seeks to analyze how the imperialcolonial phenomenon bears on constructions of the other-world, the this-world, and their relationship as advanced in the texts themselves, as construed in the established tradition of readings and readers in the West, and as offered in the contemporary production of readings and readers in the world at large' (Segovia 2005:24).

62.'The key function of postcolonial criticism is to register how the knowledge we construct and impart as academics is structured by the absence, difficulty or impossibility of representation of the subaltern. This is to recognize, however, the fundamental inadequacy of that knowledge and the institutions that contain it, and therefore the need for a radical change in the direction of a more democratic and therefore the need for a radical change in the direction of
and non-hierarchical social order' (Sugirtharajah 2002:201). 
versteekte en nagelate stemme (Kwok 1998:110), sowel as vir die protesterende stemme in die teks (kyk Sugirtharajah 1998:21). Aan die ander kant verwelkom en moedig dit bydraes van gemarginaliseerde groepe aan (Kwok 1998:110), ${ }^{63}$ beide Paulus en die gemeentelede, alhoewel soms afsonderlik. Tweedens en soos reeds geblyk het, is postkoloniale hermeneutiek geïnteresseerd in verhoudings van mag en dominasie, en die effek daarvan. Sodanige studies illustreer hoe die posisies van koloniseerder en gekolonialiseerde of magtige en magtelose gekonstrueer is, en in verband staan met mekaar, hoewel nie op gelyke vlak nie. Postkoloniale hermeneutiek benodig ' $n$ andersoortige leeshouding, wat die verhouding tussen idees en mag, taal en mag en kennis en mag kan blootlê, en kan aantoon hoe hierdie verhoudings (Westerse) tekste, teorieë en kennis in stand hou ${ }^{64}$ (Sugirtharajah 1998:16-17). Ryke het juis mense soos Paulus nodig, waar die een wat gely het onder die Ryk (1 Kor 10-13), die Ryk subtiel en by tye direk uitdaag (bv. 1 Tess 5:2), nietemin assimileer tot die imperiale manier van doen. En in die derde plek kan postkoloniale hermeneutiek nuttig aangewend word om die effek van sodanige interaksies en die hibriditeite wat daarop volg te ondersoek. Postkoloniale hermeneutiek fokus op die opneem en propagering van ' $\mathrm{n}$ nuwe of andersoortige identiteit. Gedagtig aan die belang van hibriditeit, ${ }^{65}$ word identiteit verstaan as gebroke, meervoudig en dinamies, aangesien dit bestaan binne 'a complex web of cultural negotiation and interaction, forged by imaginatively redeploying the local and the imported elements' (Sugirtharajah 1998:16-17). Paulus word miskien geen nuwe keiser nie, maar neem hy nie wel die rol van 'agent' van die Ryk op nie?

In terme van die spektrum van ondersoeksmoontlikhede voeg postkoloniale teorie waarde toe aan Bybelse hermeneutiek met die fokus op die erkenning, ondersoek en verduideliking van die kontekste van die ontstaan van Bybelse en verwante, kontemporêre tekste. 'n Postkoloniale optiek is in die besonder geïntereseerd in hoe tekste deur imperiale, sosio-kulturele en ekonomies-politieke magte beïnvloed is in die verlede en hede, en hoe sodanige invloed met gepaste raamwerke geïnterpreteer kan word. In Nuwe Testament navorsing bied postkoloniale teorie 'n bruikbare teoretiese posisie vir die interpretasie van tekste wat ontstaan het in kontekste wat deur die Romeinse Ryk oorheers is. ' $n$ Postkoloniale lees gaan verder as ' $n$ antiimperiale lees, ${ }^{66}$ en ondersoek ook dit wat die postkoloniale

63.Postkoloniale bybelinterpretasie romantiseer of idealiseer nie armes nie, en weier om die slagoffers te blameer; maar stel eerder ondersoek in na sosiale en ander strukture wat slagofferskap bevorder of daartoe bydra (Sugirtharajah 1998:22-23).

64.Met betrekking tot dekolonialiserende studies se kolonialiteit van bestaan (en van mag en van kennis) (Mignolo 2007; Maldonado-Torres 2007) in gedagte, is ' $n$ 'postkolonialiteit van bestaan' waarskynlik selfs beter in staat om in antieke en moderne tekste en kontekste ongelyke magsverhoudings te verduidelik.

65.Postkoloniale hermeneutiek fokus ook op die verkryging en propagering van ' $\mathrm{n}$ nuwe identiteit, te midde van hibriditeit, ' $n$ konsep waarvoor Bhabha bekend is: 'a doubling, dissembling image of being in at least two places at once', en daarom is koloniale andersheid gevestig in verwydering, in eenkant-wees, eerder as in spesifieke, essensialistiese identiteit (kyk Wan 2000:110)

66.Terminologie is, ten dele, die probleem hier, aangesien alle vorme van politieke oorheersing in die Bybel nie summier as 'Ryk' ('empire') verstaan kan word nie, soos sommige geleerdes nietemin beweer (kyk Bryan 2005). Groter sensitiwiteit is nodig vir waarskynlike sosio-historiese kontekste sowel as die kompleksiteite en nuases verweef met Ryk. en die imperiale vorm. ${ }^{67}$ Deur te let op oppervlakte- en onder die oppervlaktespanning in tekste bied postkoloniale kritiek die geleentheid om 'n Ryk nie alleen as materiële konteks maar ook as heuristiese raamwerk vir Bybelse interpretasie effektief te gebruik (kyk Punt 2010a). ${ }^{68}$

\section{Slot}

Die ambivalensie van mag in die Bybel, Nuwe Testament of Pauliniese briewe kan nie ontrafel word met die aanloklike maar nietemin misleidende voorstel wat aandring op 'n skeiding tussen die Bybel en God nie. As dit so is dat die Bybel 'presents the radicality of a just and nonviolent God repeatedly and relentlessly confronting the normalcy of an unjust and violent civilization', hoe kan die ambivalensie van mag in die Bybel opgelos word deur te kies vir 'the person, not the book, and the life, not the text [as] decisive and constitutive for us' (Crossan 2007:93-94)? Veral as God deur hierdie tekste gemedieer of geken word? Die voorstel verberg meer as wat dit openbaar, en ontken die ambivalensie wat dinamika van mag kenmerk, in 'n oënskynlik teodiseegedrewe behoefte om die God van die Bybel te red, al word die Bybel die sondebok. Die voorstel dryf 'n wig in tussen Bybel en God van die Bybel, met die dryfkrag veral gerig op die moderne tyd, en dra weinig by om die ambivalensie van die Bybel ten opsigte van mag te verduidelik.

Deur Paulus te verstaan as iemand wat die retoriek eie aan die Ryk opgeneem het, imperiale mag nuut uitgerus het deur die propaganda en strukture wat van die Romeinse Ryk afkomstig was te herontplooi, om sodoende sy eie posisie en boodskap te vestig en te legitimeer, word dit duidelik waarom Paulus hom nie volledig kon distansieer van die taal van dominasie en hegemonie nie. ${ }^{69}$ Die invloed van die Pauliniese tradisie in die vroeë en latere Christelike kerk, en die ongemaklike historiese getuienis van onderdrukkende Christelike ryke, sekulêr en godsdienstig, laat ons met 'n tweevoudige uitdaging. Eerstens, om alternatiewe nie-hegemoniese vorms van verhoudings in Christelike gemeenskappe te formuleer, en tweedens en net so belangrik, om gepaste hermeneutiese benaderings te vind waarmee die Bybelse tekste gelees kan word, ten einde onderdrukkende aspekte te ontbloot én dit te kan opdiep wat moontlik die basis sal vorm van die soortgelyke en regverdige verhoudings en strukture waarna mense vandag strewe. ${ }^{70}$

67.Aan die een kant was imperiale-koloniale kontak nog altyd meervoudig en meerduidig (Segovia 2005:68); aan die ander kant moet (post)koloniale en imperiale ondersoek van mekaar onderskei word (Segovia 2000:133-135)

68.' $n$ Historiese perspektief, en krities boonop, is uiters belangrik in postkoloniale werk, maar dit is ' $n$ vraag of 'postcolonial criticism does not reject the insights of historical criticism' soos Kwok (2005:80) beweer; kyk in teenstelling Segovia (1995:278-285, 2000:39); oor gevaarlike 'promiscuous marriages' van teoretiese perspektiewe of raamwerke, kyk Schüssler Fiorenza (1999:38-39). Aan die ander kant word die waarde van historiese kritiek se suspisie teenoor en teen-die-grein lesings van ekklesiaal-verordende interpretasies nie ontken nie (kyk Barton 1998:1619).

69.Volgens Horsley beteken dit die taal van kuriargie, 'the rule of the lords, emperors, kings, slave masters, and patriarchs. In imagining how the one true God would
finally bring judgment upon oppressive imperial rulers, many biblical texts portray God and the heavenly armies as exercising violence, whether figurative or literal' (Horsley 2008:182). Of anders gestel, 'there is the inevitable danger that or literal' (Horsley 2008:182). Of anders gestel, 'there is the inevitable danger that
appropriating imperial terminology for subversive purposes can be simply reversed at a later stage to become a relegitimation of empire' (Jennings 2009:151). Die geldigheid van sodanige uitsprake kan met die nalatenskap van Paulus in die vroeë en latere Christelike kerk, en ook die breër samelewing gekorreleer word.

70.Kyk Elliott (2008a:112-113) vir die VSA konteks. En ook Sugirtharajah (2007:457) se uitspraak: 'Paul's universal gospel, which flattened significant ethnic or cultural differences, has become less tenable in a postcolonial context when vernacular identities and values have a renewed lease of life." 


\section{Erkenning Mededingende belange}

Die outeur verklaar dat hy geen finansiële of persoonlike verbintenis het met enige party wat hom nadelig kon beïnvloed in die skryf van hierdie artikel.

\section{Literatuurverwysings}

Aasgaard, R., 2007, 'Paul as Child: Children and Childhood in the Letters of the Apostle', Journal of Biblical Literature 126(1), 129-159.

Ando, C., 2000, Imperial Ideology and Provincial Loyalty in the Roman Empire, University of California Press, Berkeley. (Classics and Contemporary Thought, vol. 6)

Barton, J., 1998, 'Historical-Critical Approaches', in J. Barton (ed.), The Cambridge Companion to Biblical Interpretation, pp. 9-20, Cambridge, Cambridge University Press. (Cambridge Companions to Religion).

Bassler, J.M., 2007, Navigating Paul: An Introduction to Key Theological Concepts, Westminster John Knox, Louisville/London.

Black, D.A., 1984, Paul, Apostle of Weakness: Astheneia and lts Cognates in the Pauline Literature, Peter Lang, New York.

Boers, H., 2006, 'The Meaning of Christ's Resurrection in Paul', in J.H. Charlesworth, C.D. Elledge, J.L. Crenshaw, H. Boers \& W.W. Willis (jr.) (eds.), Resurrection: The Origin and Future of a Biblical Doctrine, pp. 106-137, T \& T Clark, New York/ Origin and Future of a Biblical Doctrine, $\mathrm{pp}$. 106
London. (Faith and Scholarship Colloquies Series).

Bourdieu, P., 1977, Outline of a Theory of Practice, transl. R. Nice, Cambridge University Press, Cambridge.

Boyarin, D., 1994, A Radical Jew: Paul and the Politics of Identity, University of California Press, Berkeley. (Critical Studies in Jewish Literature, Culture, and Society, vol. 1).

Briggs, S., 2000, 'Paul on Bondage and Freedom in Imperial Roman Society', in R.A Horsley (ed.), Paul and Politics: Ekklesia, Israel, Imperium, Interpretation: Essays in Honor of Krister Stendahl, pp. 110-123, Trinity Press International, Harrisville.

Bryan, C. 2005, Render to Caesar: Jesus, the Early Church and the Roman Superpower, Oxford University Press, Oxford.

Carter, W., 2010, 'Paul and the Roman Empire: Recent Perspectives', in M.D. Given (ed.), Paul Unbound: Other Perspectives on the Apostle, pp. 7-26, Hendrickson, Peabody.

Castelli, E., 1991, Imitating Paul: A Discourse of Power, Westminster/John Knox Press, Louisville. (Literary Currents in Biblical Interpretation).

Collins, R.F., 2008, The Power of Images in Paul, Liturgical Press (Michael Glazier), Collegeville.

Cook, R.B., 2002, 'Paul and the Victims of his Persecution: The Opponents in Galatia', Biblical Theology Bulletin 32, 182-191.

Crossan, J.D., 2007, God \& Empire: Jesus Against Rome, Then and Now, Harper, San Francisco.

Crossan, J.D., 2008, 'Roman Imperial Theology', in R.A. Horsley (ed.), In the Shadow of Empire: Reclaiming the Bible as a History of Faithful Resistance, pp. 59-73, Westminster John Knox, Louisville.

Desjardins, M., 1997, Peace, Violence and the New Testament, Sheffield Academic Press, Sheffield.

Dijkhuizen, P., 2010, 'Accounting for the Shape of Early Christian Identities: Comparing Methodological Atheism and Methodological Agnosticism in the Study of Religion', paper presented at the Second Unisa colloquium, Unisa, Pretoria, 06-08 October

Eastman, S., 2007, Recovering Paul's Mother Tongue: Language and Theology in Galatians, Eerdmans, Grand Rapids.

Ehrensperger, K., 2009, Paul and the Dynamics of Power: Communication and Interaction in the Early Christ-Movement, T \& T Clark, London.

Elliott, N., 2004, 'The Apostle Paul's Self-Presentation As Anti-Imperial Performance', in R.A. Horsley (ed.), Paul and the Roman Imperial Order, pp. 67-88, Trinity Press International, Harrisville.

Elliott, N., 2007, 'Political Formation in the Letter to the Romans', in R.L. Brawley (ed.), Character Ethics and the New Testament: Moral Dimensions of Scripture, pp. 179-190, WJK, Louisville.

Elliott, N., 2008a, 'The Apostle Paul and Empire', in R.A. Horsley (ed.), In the Shadow of Empire: Reclaiming the Bible as a History of Faithful Resistance, pp. 97-116, Westminster John Knox, Louisville.

Elliott, N., 2008b, The Arrogance of Nations: Reading Romans in the Shadow of Empire, Fortress, Minneapolis. (Paul in Critical Contexts).

Elliott, S.S., 2011, "'Thanks, But No Thanks": Tact, Persuasion, and the Negotiation of Power in Paul's Letter to Philemon', New Testament Studies 57(1), 51-64. http:// dx.doi.org/10.1017/S0028688510000238

Fowl, S.E., 1994. 'Who Can Read Abraham's Story? Allegory and Interpretive Power in Galatians', Journal for the Study of the New Testament 55, 77-95.

Foucault, M. 1978, The History of Sexuality. Vol 1: An Introduction, transl. R. Hurley, Pantheon Books, New York.

Friesen, S.J., 2001, Imperial Cults and the Apocalypse of John: Reading Revelation in the Ruins, Oxford University Press, Oxford. http://dx.doi. org/10.1093/0195131533.001.0001
Gaventa, B.R., 2007, Our Mother Saint Paul, WJK, Louisville/London.

Given, M.D., 2001, Paul's True Rhetoric: Ambiguity, Cunning, and Deception in Greece and Rome, Trinity Press International, Harrisburg. (Emory Studies in Early Christianity).

Given, M.D., 2010, 'Paul and Rhetoric: A Sophos in the Kingdom of God', in M.D. Given (ed.), Paul Unbound: Other Perspectives on the Apostle, pp. 175-200, Hendrickson, Peabody.

Glancy, J.A., 2004, 'Boasting of Beatings (2 Corinthians 11:23-25)', Journal of Biblical Literature 123(1), 99-135. http://dx.doi.org/10.2307/3268552

Hays, R.B., 1989, Echoes of Scripture in the letters of Paul, Yale University Press, New Haven/London.

Hollingshead, J.R., 1998, The Household of Caesar and the Body of Christ: A Political Interpretation of the Letters from Paul, University Press of America, Lanham.

Holmberg, B., 1978, Paul and Power: The Structure of Authority in the Primitive Church As Reflected in the Pauline Epistles, Gleerup, Lund. (Coniectanea Biblica, New Testament Series, vol. 11).

Horsley, R.A., 1997 ' 1 Corinthians: A Case Study of Paul's Assembly as an Alternative Society', in R.A. Horsley (ed.), Paul and Empire: Religion and Power in Roman Imperial Society, pp. 242-252, Trinity Press International, Harrisville.

Horsley, R.A., 2008, 'Conclusion', in R.A. Horsley (ed.), In the Shadow of Empire: Reclaiming the Bible As a History of Faithful Resistance, pp. 177-182, Westminster John Knox, Louisville.

Jennings, T.W. (jr.), 2009, 'Paul against Empire: Then and Now', in A.F. Botta \& P.R. Andiñach (eds.), The Bible and the Hermeneutics of Liberation, pp. 147-167, SBL, Atlanta. (Society of Biblical Literature Semeia Studies vol. 59).

Johnson, L.T., 1998, Religious Experience in Earliest Christianity: A Missing Dimension in New Testament Studies, Fortress, Minneapolis.

Kim, Y.S., 2008, Christ's Body in Corinth: The Politics of a Metaphor, Fortress, Minneapolis. (Paul in Critical Contexts Series).

Kittredge, C.B., 1998, Community and Authority: The Rhetoric of Obedience in the Pauline Tradition, Trinity Press International, Harrisburg. (Harvard Theological Studies, vol. 45).

Konstan, D., 2005, 'Clemency as a Virtue', Classical Philology 100(4), 337-346. http:// dx.doi.org/10.1086/500436

Kwok, P., 1998, 'Reflection on Women's Sacred Scriptures', Concilium 3, 105-112.

Kwok, P., 2005, Postcolonial Imagination and Feminist Theology, WJK, Louisville.

Lieu, J., 1986, The Second and Third Epistles of John: History and background, T \& T Clark, Edinburgh. (Studies of the New Testament and its world). http://dx.doi. org/10.1093/0199262896.001.0001

Lieu, J.M., 2004, Christian Identity in the Jewish and Graeco-Roman World, Oxford University Press, Oxford.

Malina, B.J. \& Neyrey, J.H., 1996, Portraits of Paul: An Archeology of Ancient Personality, WJK, Louisville.

Mann, M., 1986, The Sources of Social Power: Volume 1: A History of Power from the Beginning to $A D$ 1760, Cambridge University Press, Cambridge.

Marchal, J.A., 2008, The Politics of Heaven: Women, Gender, and Empire in the Study of Paul, Fortress, Minneapolis. (Paul in Critical Contexts).

Martin, D.B., 1995, The Corinthian Body, Yale University Press, New Haven/London.

Matthews, S., 2009, 'Clemency as Cruelty: Forgivneness and Force in the Dying Prayers of Jesus and Stephen', Biblical Interpretation 17, 118-146. http://dx.doi. org/10.1163/156851508X383412

Maldonado-Torres, N., 2007, 'On the Coloniality of Being. Contributions to the Development of a Concept', Cultural Studies 21(2), 240-270.

Mignolo, W.D., 2007, 'Introduction. Coloniality of Power and De-Colonial Thinking', Cultural Studies 21(2/3), 155-167.

Morgan, D., 1998, Visual Piety: A History and Theory of Popular Religious Images, University of California Press, Berkeley.

Patte, D., 1983, Paul's Faith and the Power of the Gospel: A Structural Introduction to the Pauline Letters, Fortress, Philadelphia.

Polaski, S.H., 1999, Paul and the Discourse of Power, Sheffield Academic Press, Sheffield. (Gender, Culture, Theory vol. 8).

Polaski, S.H., 2005, A Feminist Introduction to Paul, Chalice, St Louis.

Price, S.R.F., 1984, Rituals and Power: The Roman Imperial Cult in Asia Minor, Cambridge University Press, Cambridge.

Price, S.R.F., 1997, 'Rituals and Power', in R.A. Horsley (ed.), Paul and Empire: Religion and Power in Roman Imperial Society, pp. 47-71, Trinity Press International, Harrisville.

Punt, J., 2008, 'Paul and postcolonial hermeneutics: Marginality and/in early biblical interpretation', in S. Porter \& C.D. Stanley (ed.), As it is written: Studying Paul's use of Scripture, pp. 261-290, SBL, Atlanta. (Society of Biblical Literature Symposium Series, vol. 50).

Punt, J., 2010a, 'Empire as Material Setting and Heuristic Grid for New Testament Interpretation: Comments on the Value of Postcolonial Criticism', HTS Teologiese Studies/Theological Studies 66(1), Art. \#330, 7 pages. http://dx.doi.org/10.4102/ hts.v66i1.330

Punt, J., 2010b, 'Paul, Power and Philemon. "Knowing Your Place": A Postcolonial Reading', in F. Tolmie (ed.), Philemon in Perspective: Interpreting a Pauline Letter, pp. 223-250, Walter De Gruyter, Berlin/New York. (Beihefte zur ZNW, vol. 169).

Punt, J., 2010c, 'Power and liminality, sex and gender, and Gal 3:28: A postcolonial, queer reading of an influential text', Neotestamentica 44(1), 140-166. 
Punt, J., 2011a, Identity, memory and scriptural warrant: Arguing Paul's case (forthcoming).

Punt, J., 2011b, 'Paul, body, and resurrection in an imperial setting: Considering hermeneutics and power', Neotestamentica 45(2), 311-330.

Reasoner, M., 1999, The Strong and the Weak: Romans 14:1-15:13 in Context Cambridge University Press, Cambridge. (SNTS Mongraph Series vol. 103).

Ricoeur, P., 1980, Essays on Biblical Interpretation, ed. and intro. L.S. Mudge, Fortress, Philadelphia.

Rieger, J., 2007, Christ and Empire: From Paul to Postcolonial Times, Fortress, Minneapolis.

Rowland, C., 2006, 'Social, Political, and Ideological Criticism', in J.W. Rogerson and JM. Lieu (eds.). The Oxford Handbook of Biblical Studies, pp. 655-671, Oxford University Press, Oxford/New York.

Saunders, R., 2005, 'Paul and the Imperial Cult', in S.E. Porter (ed.), Paul and His Opponents, pp. 227-238, Brill, Leiden/Boston. (Pauline Studies vol. 2).

Savage, T.B., 1996, Power through Weakness: Paul's Understanding of the Ministry in 2 Corinthians, Cambridge University Press, Cambridge. (SNTS Monograph Series, vol. 86).

Schüssler Fiorenza, E., 1999, Rhetoric and Ethic: The Politics of Biblical Studies, Fortress, Minneapolis.

Schüssler Fiorenza, E., 2000, 'Paul and the politics of interpretation', in R.A. Horsley (ed.), Paul and politics: Ekklesia, Israel, Imperium, Interpretation: Essays in honour of Krister Stendahl, pp. 40-57, TPI, Harrisburg.

Scott, J.M., 1993, "“For as Many as Are of the Works of the Law Are Under a Curse" (Galatians 3.10)', in C.A. Evans \& J.A. Sanders (eds.), Paul and the Scriptures of Israel, pp. 187-221, Sheffield Academic Press, Sheffield. (JSNT Supplement Series. Studies in Scripture in Early Judaism and Christianity, 1 vol. 83).

Segal, A.F., 2000, 'Response: Some Aspects of Conversion and Identity Formation in the Christian Community of Paul's Time', in R.A. Horsley (ed.), Paul and Politics: Ekklesia, Israel, Imperium, Interpretation: Essays in Honor of Krister Stendahl, pp. 184-190, Trinity Press International, Harrisville.

Segovia, F.F., 1995, 'The Text as Other: Towards a Hispanic American Hermeneutic', in D. Smith-Christopher (ed.), Text \& experience: Towards a cultural exegesis of the Bible, pp. 276-198, Biblical Seminar, Sheffield Academic Press, Sheffield.

Segovia, F.F., 1998, 'Biblical Criticism and Postcolonial Studies: Towards a Postcolonial Optic', in R.S. Sugirtharajah (ed.), The Postcolonial Bible, pp. 49-65, Sheffield Academic Press, Sheffield. (The Bible and Postcolonialism).

Segovia, F.F., 2000, Decolonizing Biblical Studies: A View From the Margins, Orbis, Maryknoll.

Segovia, F.F., 2005, 'Mapping the Postcolonial Optic in Biblical Criticism: Meaning and Scope', in S.D. Moore \& F.F. Segovia (eds.), Postcolonial Biblical Criticism: Interdisciplinary intersections, pp. 23-78, T \& T Clark International, London/New York. (The Bible and Postcolonialism)

Segovia, F.F. \& Tolbert, M.A. (eds.), 1995a, Reading From This Place: Vol. 1: Socia Location and Biblical Interpretation in the United States, Fortress, Minneapolis.
Segovia, F.F. \& Tolbert, M.A. (eds.), 1995b, Reading Form This Place: Vol. 2: Social Location and Interpretation in Global Perspective, Fortress, Minneapolis.

Silva, M., 1993, 'Old Testament in Paul', in G.F. Hawthorne, R.P. Martin \& D.G. Reid (eds.), Dictionary of Paul and His Letters, pp. 630-642, InterVarsity Press, Leicester.

Stanley, C.D., 2004, Arguing with Scripture: The Rhetoric of Quotations in the Letters of Paul, T\&T Clark International, New York/London.

Stirewalt, M. L., 2003, Paul, the Letter Writer, Eerdmans, Grand Rapids.

Stockhausen, C.K., 1990, 'Paul the Exegete', Bible Today 28(4), 196-202.

Sugirtharajah, R.S., 1998, Asian Biblical Hermeneutics and Postcolonialism: Contesting the Interpretations, Orbis, Maryknoll. (The Bible and Liberation Series).

Sugirtharajah, R.S., 2002, Postcolonial Criticism and Biblical Interpretation, Oxford University Press, Oxford.

Sugirtharajah, R.S., 2007, 'Postcolonial and Biblical Interpretation: The Next Phase', in F.F. Segovia \& R.S. Sugirtharajah (eds.), A Postcolonial Commentary on the New Testament Writings, pp. 455-466, T \& T Clark, New York. (The Bible and Postcolonialism, vol. 13).

Thiselton, A.C., 1980, The Two Horizons: New Testament Hermeneutics and Philosophical Description with Special Reference to Heidegger, Bultmann, Gadamer, and Wittgenstein, Eerdmans, Grand Rapids.

Verhey, A., 1984, The Great Reversal: Ethics and the New Testament, Eerdmans, Grand Rapids.

Walsh, R., 2005, Finding St Paul in Film, T \& T Clark, New York/London.

Wan, S., 2000, 'Does Diaspora Identity Imply Some Sort of Universality? An AsianAmerican Reading of Galatians', in F.F. Segovia (ed.), Bible and Postcolonialism, pp. 107-131, Sheffield Academic Press, Sheffield.

Wan, S., 2008, 'Ecstasy and Exousia: Religious Experience and the Negotiation of Social Power in Paul's Letter to the Galatians', in M.F. Foskett \& O.W. Allen (jr.) (eds.), Between Experience and Interpretation: Engaging the Writings of the New Testament, pp. 67-81, Abingdon, Nashville.

Wanamaker, C.A., 2003,"'By the Power of God". Rhetoric and Ideology in 2 Corinthians 10-13', in D.B. Gowler, L.G. Bloomquist \& D.F. Watson (eds.), Fabrics of Discourse: Essays in Honor of Vernon K Robbins, pp. 194-221, Trinity Press International, Harrisburg.

Witherington III, B., 2003, 'Contemporary Perspectives on Paul', in J.D.G. Dunn (ed.), The Cambridge Companion to St Paul, pp. 256-269, Cambridge University Press, Cambridge. (Cambridge Companions to Religion).

Wright, N.T., 2000, 'Paul's Gospel and Caesar's Empire', in R.A. Horsley (ed.), Paul and Politics: Ekklesia, Israel, Imperium, Interpretation: Essays in Honor of Krister Stendahl, pp. 160-183, Trinity Press International, Harrisville.

Wright, N.T., 2005, Paul: In Fresh Perspective, Fortress, Minneapolis.

Xu, B., 1994, 'Memory and the Ethnic Self: Reading Amy Tan's The Joy Luck Club', in A. Singh, J.T. Skerrett (jr.) \& R.E. Hogan (eds.), Memory, Narrative, and Identity: New Essays in Ethnic American Literatures, pp. 261-277, Northeastern University Press, Boston.

Zanker, P., 1990, The Power of Images in the Age of Augustus, transl. A Shapiro, University of Michigan Press, Ann Arbor. (Jerome Lectures Series 16). 